\title{
Geranium pseudodiffusum (Geraniaceae), a New Species from Ecuador and Peru
}

\author{
Carlos Aedo \\ Real Jardín Botánico, CSIC, Plaza de Murillo 2, 28014 Madrid, Spain. (aedo@rjb.csic.es)
}

Communicating editor: Tom Ranker

\begin{abstract}
A new species of sect. Diffusa, Geranium pseudodiffusum (Geraniaceae) found in Ecuador and Peru is described. The new species is morphologically most similar to G. diffusum. Leaves of G. diffusum are \pm densely covered by small and appressed hairs on both surfaces, while in G. pseudodiffusum hairs are restricted to margin and nerves of the abaxial side and more rarely on nerves of the adaxial side. Additionally, G. pseudodiffusum has glandular hairs on the stems, pedicels, sepals, petioles, and sometimes on the leaf lamina, while in G. diffusum only eglandular hairs are present. A morphological comparison to related species, and a new key for the whole section is provided. In addition, a detailed description, distribution map, habitat and line drawing are provided for this new species.
\end{abstract}

Keywords_-Andes, Ecuador, Geraniaceae, Geranium, Peru, South America.

The genus Geranium L. comprises about 350 species distributed throughout most of the world. South America is the richest area of the world, with over 100 species. Most of these species belong in subg. Geranium. The exceptions are section Brasiliensia R. Knuth (Aedo 2001a) included in subg. Erodioidea (Picard) Yeo and some nonnative representatives of subg. Robertium (Picard) Rouy (Aedo et al. 1998). The genus was monographed by Knuth (1912), but no recent revisions for South America are available. Aedo $(2000,2001 b)$ revised Geranium in North America and Moore (1943) in Central America, but there are no native species in these revisions that occur south of Panama.

In pursuit of my aim to prepare a comprehensive monograph of the genus I have studied some sections of Geranium from South America (Aedo 2001a, Aedo et al. 2002, 2003, 2005). One group not yet monographed is sect. Diffusa R. Knuth. This section includes six species with 1-flowered cymules, which share a decumbent habit, turnip-shaped rootstocks, short leaves, and short petals. This section is distributed in the Andes from West Venezuela to South Peru, although the highest diversity of species is found in Ecuador (five species) and Peru (three species). While I was preparing the taxonomic monograph of sect. Diffusa, I realized that some specimens did not fit with any previously described species. In this paper, these plants are described as a new species of Geranium.

\section{TAxonomic Treatment}

Geranium pseudodiffusum Aedo, sp. nov.-TYPE: ECUADOR. Azuay, páramo de Cajas, Chuspipuñuna, 20 July 2006, Aedo \& Ulloa 13101 (holotype: MA!; isotypes: MO!, QCNE!).

A simili Geranium diffusum Kunth, pilis glanduliferis prorsus destituto, aperte differt cum eiusmodi pilis tam caule quam petiolis, foliorum basi etiamque inflorescentia-sepalis pedicellisque praecipue-praeditum sit.

Herbs perennial, 3-17 cm tall. Rootstock 1-11 mm diam., \pm vertical. Stem $0.06-0.22 \mathrm{~cm}$ diam., decumbent, without vegetative stems, leaved, herbaceous, with retrorse, appressed, eglandular hairs $0.2-1.5 \mathrm{~mm}$ long, and patent, glandular hairs $0.2-0.5 \mathrm{~mm}$ long. Basal leaves in a \pm persistent rosette; lamina 0.5-2.9 $\times 0.7-2.7 \mathrm{~cm}$, polygonal in outline, cordate, palmatifid (ratio main-sinus length / middle-segment length = (0.74)0.88-0.91(0.98)), pilose, with appressed, eglandular hairs and scattered, patent glandular hairs on margin and on nerves of the abaxial side (sometimes on adaxial nerves too), nervation not projected; segments 5, obtriangular (with lanceolate lateral lobes joined to the middle one) (ratio maximum width / middle-segment length $=(0.76) 0.92-0.98), 0.5-1.4 \mathrm{~mm}$ wide at the base, 3(5)-lobed at the apex (ratio second-sinus length / middle-segment length $=(0.31) 0.44-0.52(0.61))$; cauline leaves opposite; petioles to $17 \mathrm{~cm}$ long, with retrorse, appressed, eglandular hairs $0.3-0.7 \mathrm{~mm}$ long, and patent, glandular hairs $0.2-0.5 \mathrm{~mm}$ long; stipules $2.8-6.8 \times 1-1.8 \mathrm{~mm}$, lanceolate, with scattered eglandular hairs on abaxial surface and on the margin, glabrous adaxially. Inflorescence a monochasialcyme; cymules 1-flowered, solitary; pedicels $2.3-20.5 \mathrm{~cm}$ long, with retrorse, appressed, eglandular hairs $0.2-0.7 \mathrm{~mm}$ long, and patent, glandular hairs $0.2-0.6 \mathrm{~mm}$ long. Sepals 3.9-5.7 × 1-2.1 mm, not accrescent, 3-nerved, with mucro 0.4$0.8 \mathrm{~mm}$ long, with scarious margins $0.1-0.2 \mathrm{~mm}$ wide, with erect-patent, eglandular hairs $0.2-0.7 \mathrm{~mm}$ long and glandular hairs $0.2-0.4 \mathrm{~mm}$ long on abaxial side, minutely hairy adaxially. Petals 4.8-7.1 $\times 1.2-2.2 \mathrm{~mm}$ (ratio petal wide/petal length $=$ 0.26-0.44), erect-patent, entire, glabrous, white or pale pink. Staminal filaments 2.1-3 mm long, lanceolate, with eglandular hairs $0.2-0.3 \mathrm{~mm}$ long on the abaxial side and margin; anthers $0.4-0.7 \times 0.3-0.5 \mathrm{~mm}$, yellowish; pollen yellowish. Nectaries 5, hemispheric, glabrous. Gynoecium 2.4-3.2 mm long. Fruit 6.4-11.2 mm long; mericarps 1.8-2.6 $\times 0.8-1.3 \mathrm{~mm}$, with erectpatent, eglandular hairs $0.1-0.5 \mathrm{~mm}$ long and sometimes glandular hairs 0.1-0.4 mm long, brownish; rostrum 3.9-6.6 mm long, without a narrowed apex, with erect-patent, eglandular hairs $0.1-0.3 \mathrm{~mm}$ long and sometimes glandular hairs 0.1-0.4 mm long; stigmatic remains $0.8-1.2 \mathrm{~mm}$ long, with 5 glabrous lobes. Seeds $1.3-1.8 \times 0.7-1.2 \mathrm{~mm}$, finely reticulate, brownish; hilum $1 / 6$ as long as the perimeter. Cotyledons entire. Figures 1, 2.

Additional Specimens Examined-ECUADOR. Azuay: páramo de Cajas, laguna Toreadora, 246'S, 79 $13^{\prime} \mathrm{W}, 20 \mathrm{Jul}$ 2006, Aedo E Ulloa 13105 (MA); 20 Nov 1991, Halfdan-Nielsen 51bis (C); páramo de Cajas, 18 km de Cuenca, 251'S, 798'W, 19 Nov 1991, Halfdan-Nielsen 43 (C); 20 km de Cuenca, 248'S, 799'W, 19 Nov 1991, Halfdan-Nielsen 45 (C). Chimborazo: Urbina, ladera SW del volcán Chimborazo, 31 Jul 2006, 1²7'S, 78²4'W, Aedo 13236 (MA); E volcán Chimborazo, 1²8'S, 7846'W, 22 Nov 1993, Halfdan-Nielsen 57 (C); S slope of mt Chimborazo, 1'31' S, 7849' W, Oct 1952, Fagerlind $\mathcal{E}$ Wibom 936 (S). Cotopaxi: ladera N del volcán Cotopaxi, 0³8'S, 78²6'W, 1 Aug 2006, Aedo 13340 (MA). Napo: road Quito-Baeza, near the pass at Papallacta, $0^{\circ} 20^{\prime}$ S, $78^{\circ} 12^{\prime}$ W, 30 Oct 1983 , Eriksen $\mathcal{E}$ Larsen 45446 (AAU); at laguna Papallacta, 0²1' S, 786' W, 17 Jul 1976, Ollgaard E Balslev 8029 (MO, NY). Pichincha: Chaupi, ladera NE de los volcanes Illinizas, $0^{\circ} 37^{\prime}$ S, 78²41' W, 2 Aug 2006, Aedo 13345(MA); San Ignacio, $0^{\circ} 12^{\prime}$ S, 78³3' W, 14 Aug 1923, Anthony \& Tate 142 (US); flanc E du Pichincha, 09' S, 78³3' W, 23 Mar 1930, Benoist 2222 (P); entre el refugio de Guagua Pichincha y Lloa, $0^{\circ} 10^{\prime}$ S, 78³6' W, 29 Nov 1991, Halfdan-Nielsen 79 (C); E slopes of Cerro Pichincha, 09' S, 78³3' W, 30 Dec 1919, Holmgren $\mathcal{E}$ 

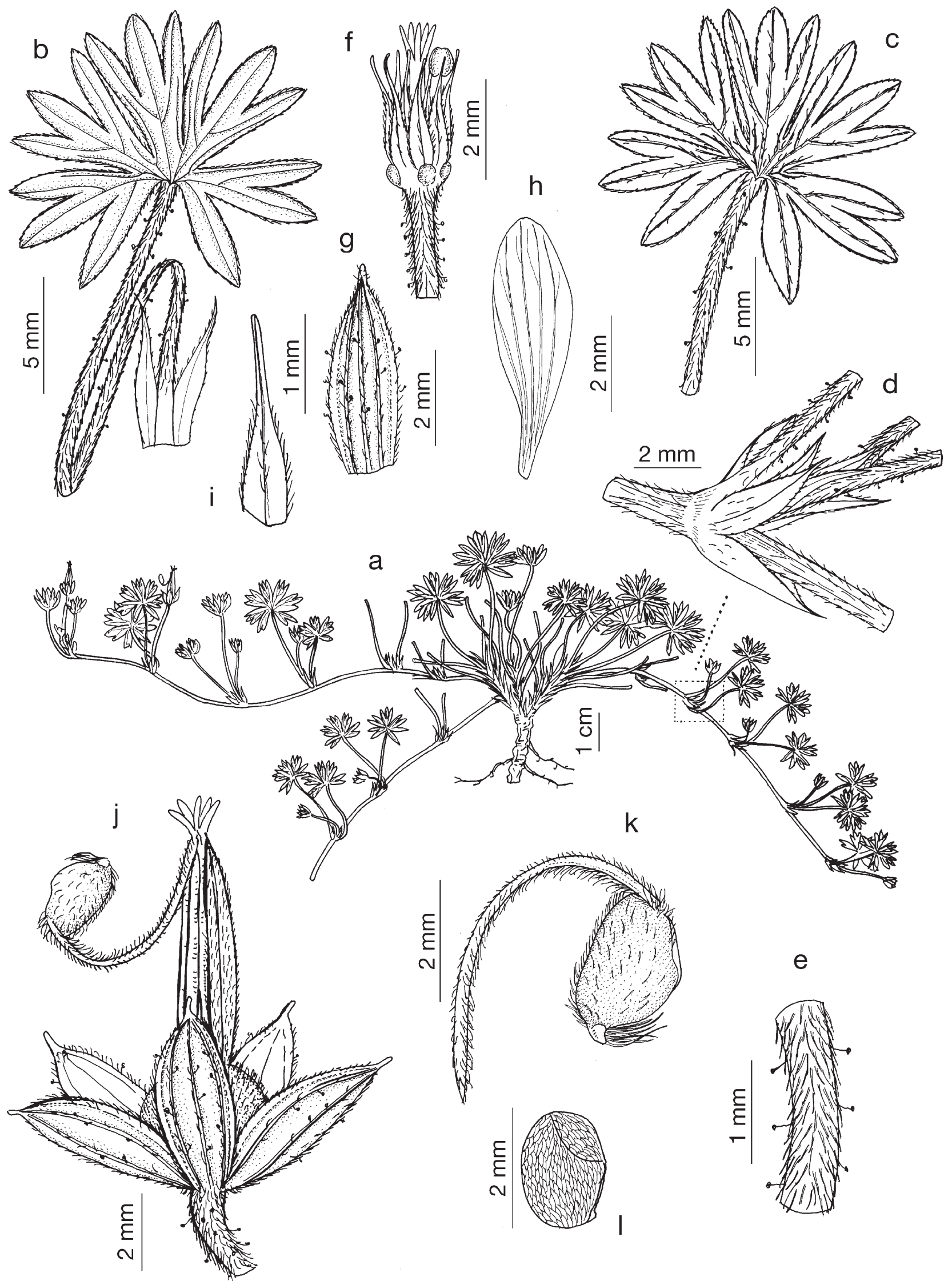

V.L. Lastillo, 2008

FIG. 1. Geranium pseudodiffusum. a. Habit. b. Leaf, adaxial side. c. Leaf, abaxial side. d. Bracteoles. e. Pedicel. f. Flower without petals and sepals. g. Sepal. h. Petal. i. Staminal filament. j. Fruit. k. Mericarp. 1. Seed. (a-1: from Aedo \& Ulloa 13101, MA). 


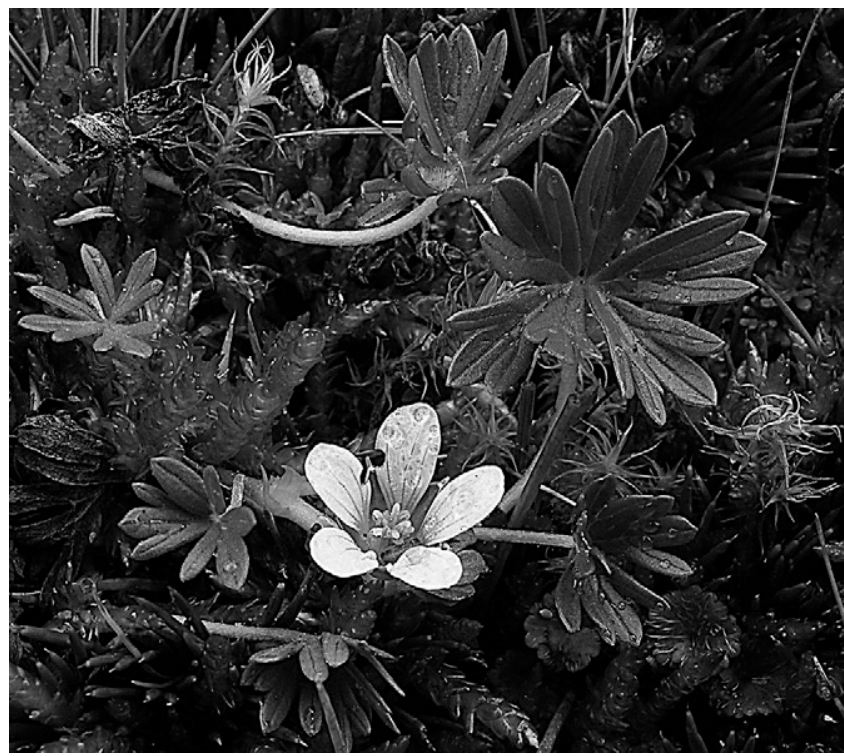

Fig. 2. Geranium pseudodiffusum in its natural habitat in paramo de Cajas (Ecuador). The photograph corresponds to the type material (Aedo $\mathcal{E}$ Ulloa 13101).

Heilborn $138 b$ (S); Andibus Ecuadoriensibus, 1857, Spruce 5014 (E). Tungurahua: valle río Colorado, $1^{\circ} 20^{\prime}$ S, 78 51' W, 22 Nov 1991, HalfdanNielsen 54 (C); Halfdan-Nielsen 55 (C).

PERU.Cajamarca: Minas Conga, sector Huaylamachay, $6^{\circ} 51^{\prime} \mathrm{S}, 78^{\circ} 21^{\prime} \mathrm{W}$, 1 Oct 2005, Granda 2477 (MA); pr. Huayllapampa, 7²12' S, 78³3' W, 15 Jun 2009, Aedo16494 (MA); cerro Yanahuanga, 652' S, 78³7' W, 17 Jun 2009, Aedo16546 (MA).

Distribution and Habitat-Ecuador, from Pichincha to Azuay provinces, and North Peru (Cajamarca). (Fig. 3). Peats or very humid habitats in Polylepis forest or open grassy areas, among 3,300 and 4,150 $\mathrm{m}$.

Phenology_Flowering from July to December.

\section{Discussion}

This species is similar to Geranium diffusum Kunth in general appearance. Leaves of G. diffusum are \pm densely covered by small and appressed hairs on both surfaces, while in G. pseudodiffusum hairs are restricted to margin and nerves of the abaxial side and more rarely on nerves of adaxial side. Additionally, G. pseudodiffusum has glandular hairs on stem, pedicels, sepals, petioles, and sometimes on leaf lamina (especially towards the base). Glandular hairs are also present on

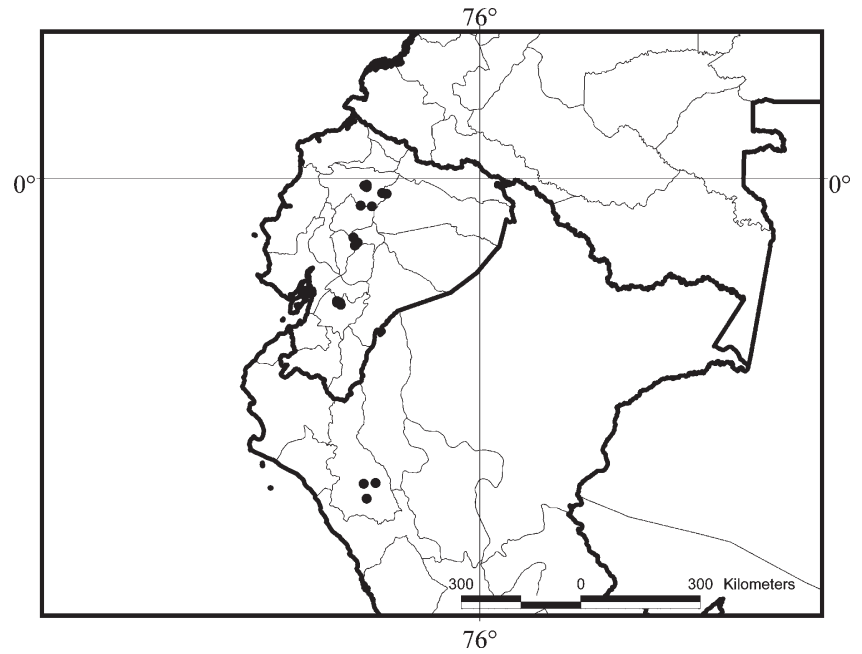

Fig. 3. Distribution of Geranium pseudodiffusum in Ecuador and North Peru.

the mericarps and rostrum of the fruit but not constantly. Geranium antisanae R. Knuth also has glandular indumentum but it is easily distinguished by its less deeply divided leaves, which are densely covered by glandular and eglandular patent hairs. Geranium pseudodiffusum is additionally different from G. diffusum in some minor quantitative features, which have some overlap. Leaves of G. pseudodiffusum are more divided because the segments and lobes have deeper sinuses. Its pedicels are shorter than in G. diffusum and thus cymules appear shorter than the adjacent leaf. Petals are shorter and narrower than in G. diffusum and always glabrous, and staminal filaments and fruits are also shorter.

Geranium pseudodiffusum is confined to paramos of central Ecuador and N Peru where G. diffusum is also found. I have collected both species in several localities where they grow together. There I could verify that G. diffusum grows in disturbed areas while G. pseudodiffusum is located in peats or humid habitats. In extreme cases G. diffusum occurs in borders of peats or even on tussocks of grasses while G. pseudodiffusum is restricted to the swampy base of these tussocks. To distinguish the species of sect. Diffusa, which exhibit decumbent habit, turnip-shaped rootstocks, 1-flowered cymules, short leaves, and short petals, a key is provided.

\section{Key to Species of Geranium Sect. Diffusa}

1. Petioles and pedicels with glandular hairs

2. Leaves deeply divided (ratio main-sinus length of the middle segment $/$ middle-segment length $=$

(0.31)0.44-0.52(0.61)), with appressed, eglandular hairs restricted to margins and nerves of abaxial side, sometimes on adaxial side too

2. Leaves not deeply divided (ratio main-sinus length of the middle segment / middle-segment length $=$

(0.20)0.25-0.31(0.36)), with patent, eglandular hairs on both sides

G. pseudodiffusum

1. Petioles and pedicels without glandular hairs

3. Leaf palmatisect

3. Leaf palmatisect

4. Petioles and peduncles with patent hairs

4. Petioles and peduncles with retrorse, adpressed hairs.

5. Leaf middle segment with 5(6) lobes

5. Leaf middle segment with (1)3(5) lobes

G. antisanae R. Knuth 
AcKNOWLEDGMENTs. The author wish to thank M. Laínz for the Latin diagnosis, and S. Castroviejo for uncompromising support. I also thank the editors and two anonymous reviewers for helpful comments. I am also grateful to the curators of the cited herbaria for kind assistance during my visits and for loan of specimens. This work was partly financed by the Spanish Dirección General de Investigación through the research project CLG2007-60184/BOS.

\section{Literature Cited}

Aedo, C. 2000. The genus Geranium L. (Geraniaceae) in North America. I. Annual species. Anales del Jardín Botánico de Madrid 58: 39-82.

Aedo, C. 2001a. Taxonomic revision of Geranium sect. Brasiliensia (Geraniaceae). Systematic Botany 26: 205-215.

Aedo, C. 2001b. The genus Geranium L. (Geraniaceae) in North America. II. Perennial species. Anales del Jardín Botánico de Madrid 59: 3-65.
Aedo, C., J. J. Aldasoro, and C. Navarro. 2002. Revision of Geranium sections Azorelloida, Neoandina and Paramensia (Geraniaceae). Blumea 47: 205-297.

Aedo, C., J.J. Aldasoro, L. Sáez, and C. Navarro. 2003. Taxonomic revision of Geranium sect. Gracilia (Geraniaceae). Brittonia 55: 93-126.

Aedo, C., F. Muñoz Garmendia, and F. Pando. 1998. World checklist of Geranium L. (Geraniaceae). Anales del Jardín Botánico de Madrid 56: 211-252.

Aedo, C., C. Navarro, and M. L. Alarcón. 2005. Taxonomic revision of Geranium sections Andina and Chilensia (Geraniaceae). Botanical Journal of the Linnean Society 149: 1-68.

Knuth, R. 1912. Geraniaceae. Das Planzenreich IV.129 (Heft 53): 1-631, ed. A. Engler Leipzig: Wilhelm Engelmann.

Moore, H.E. 1943. A revision of the genus Geranium in Mexico and Central America. Contributions from the Gray Herbarium of Harvard University 146: 1-108, 5 "Plate". 